\title{
Characterization of new variety of Chrysanthemum by using ISSR markers
}

\author{
SK Palai ${ }^{1}$; Gyana Ranjan Rout* \\ ${ }^{1}$ Regional Plant Resource Centre, Plant Biotechnology Division, Floriculture Division, Nayapalli, Bhubaneswar, 751 015, India; \\ *Communication address: grrout@rediffmail.com
}

\begin{abstract}
Chrysanthemum is the important cut flower after rose among the ornamental plants traded in the global flower market. It is propagated vegetatively and also has a strong sporophytic selfincompatibility system as shown by all members of Asteraceae family. Morphologically, the petal numbers and flower colours present maximum variation when compared to existing varieties. Twenty Inter Simple Sequence Repeat primers were used to detect the new variety of Chrysanthemum developed through spontaneous sporting. The results indicate that the rate of polymorphism showed significant differences as compared to other existing varieties. The average number of amplification products per primer was eight. The size of ISSR amplified fragments varied from $0.25-2.4 \mathrm{Kbp}$. Therefore, ISSR marker is a useful technique for the rapid and easy assessment of genetic variation among the variants. Morphological traits of new variants showed variation as compared to other parents. The $1^{\text {st }}$ flower bud appearance and the height of $1^{\text {st }}$ bud of the variant were less as compared to original mother variety. The new variants can be propagated in large scale commercially through in vitro technique.
\end{abstract}

Keywords: Chrysanthemum, sporting, variety identification, ISSR markers.

\section{RESUMO}

Caracterização de novas cultivares de crisântemo com o uso de marcadores ISSR

Entre as plantas ornamentais comercializados no mercado mundial, o crisântemo é a flor de corte de maior importância sendo superado apenas pela rosa. Ele é propagado vegetativamente e também tem um forte sistema de auto-incompatibilidade esporofítica como mostrado por todos os membros da família Asteraceae. Morfologicamente, os números de pétalas e as cores das flores apresentam variação máxima em relação às cultivares existentes. Empregou-se vinte primers ISSR (Inter Simple Sequence Repeat) para caracterizar a nova cultivar de crisântemo desenvolvida por mutação expontânea. Os resultados indicam que a taxa de polimorfismo mostrou diferenças significativas em comparação com outras cultivares existentes. Foi de oito o número médio de produtos de amplificação por primers. O tamanho dos fragmentos ISSR amplificados variou de 0,25 a 2,4 Kbp. Portanto, o marcador ISSR é uma técnica útil para a avaliação rápida e fácil de variações genéticas entre cultivares. Características morfológicas de novas cultivares apresentaram variação em comparação com outros parentais. $\mathrm{O}$ aparecimento do primeiro botão floral e a sua altura na nova cultivar foi mais tardio e mais baixo quando comparado com o progenitor feminino. As novas cultivares podem ser propagadas em larga escala comercialmente através da técnica in vitro.

Palavras-chave: Chrysanthemum, mutação, identificação de variedades, marcadores ISSR.

(Recebido para publicação em 22 de outubro de 2010; aceito em 30 de novembro de 2011) (Received on October 22, 2010; accepted on November 30, 2011)

$\mathrm{T}$ he commercial production of ornamental plants is growing worldwide. Its monetary value has significantly increased over the last two decades and there is a great potential for continued further growth in both domestic and international markets (Jain, 2002). Major pot plants such as Chrysanthemum, Begonia, Ficus, Anthurium, Rosa, Saintpaulia, and Spathiphyllum are being produced in the developed countries (Anonymous, 2003). About 212.5 million plants including 157 million ornamental plants amounting to $78 \%$ of the total production were reported (Pierik, 1991a, b). Chrysanthemum (Dendranthema grandiflora syn. Chrysanthemum morifolium Ramat.) is extensively grown as a pot plant as well as a cut flower worldwide. It is vegetatively propagated with cuttings and suckers. Breeding programs have focused on improving various characteristics to enhance ornamental values, including flower color, size and form, and production quality. It is propagated vegetatively as it has a strong sporophytic selfincompatibility system. Breeding of Chrysanthemum can be made through two ways i.e. cross between two cultivars and by spontaneously arising or artificially induced 'sports'. Sports are cultivars derived vegetatively from successful cultivars that differ from the original cultivars in some traits
(Wolff, 1996). In Chrysanthemum, there are three different cell layers that form different parts of the plant which have regenerative capacities and are genetically different from each other (Malaure et al., 1991a,b). Since, the species is chimeric, these cell layers may be genetically different. Some cultivars have a less stable phenotype than others and tend to sport more regularly (Dowrick \& El-Bayoumi, 1966). A difference between tissue layers is called a pericline chimera (Bush et al., 1993). The layers may differ in a diversity of traits, e.g. flower colors and leaf morphology. In a periclinal chimera, a bud originating from a cell of one layer may lead to a shoot with different 
flower colors than if the bud originated from a cell of another, genetically different layer (Stewart \& Dorman, 1970). It is propagated vegetatively and also develops new variants, either through breeding spontaneously or artificially induced 'sports'. Spray type has marketable importance for export. The number of molecular markers has been used to detect the variants in ornamental plants (Rout \& Mohapatra, 2006). The Inter Simple Sequence Repeat technique is highly informative to detect the new variety (Guasmi et al., 2006; Rout \& Aparajita, 2009). A large number of markers are easily generated; it is a technique reliable, reproducible (Chatti et al., 2007; Aparajita \& Rout, 2010). In this communication, we report the new variants developed through sports and identified with existing varieties using ISSR markers.

\section{MATERIAL AND METHODS}

Commercial varieties were selected to produce variants. The selected varieties were cultivated in the Chrysanthemum germplasm garden established by the Indian Council of Agricultural Research, Bhubaneswar. Leaf material was collected from both from new variants and close related identified varieties. The morphological traits of both variants and close related identified varieties were indicated in Table 1.

\section{DNA isolation and quantification} - The DNA was extracted from fresh leaves of each cultivar by using the cetyltrimethyl ammonium bromide (CTAB) reported earlier (Doyle \& Doyle, 1990). Approx. $200 \mathrm{mg}$ of fresh leaves was ground to powder in liquid nitrogen using a mortar and pestle. The ground powder was transferred to a $50 \mathrm{~mL}$ falcon tube with $10 \mathrm{~mL}$ of CTAB buffer [2\% (w/v) CTAB, $1.4 \mathrm{M} \mathrm{NaCl}, 20 \mathrm{mM}$ EDTA, $100 \mathrm{mM}$ Tris [tri (hydroxymethyl) amino methane]-HCl, $\mathrm{pH} 8.0$, and $0.2 \%$ (v/v) $\beta$-mercaptoethanol. The homogenate was incubated at $60^{\circ} \mathrm{C}$ for $2 \mathrm{~h}$, extracted with an equal volume of chloroform/isoamyl alcohol $(24: 1 \mathrm{v} / \mathrm{v})$ and centrifuged at $10,000 \times \mathrm{g}$ for $20 \mathrm{~min}$. DNA was precipitated from the aqueous phase by mixing with an equal volume of isopropanol. After centrifugation at $10,000 \times g$ for $10 \mathrm{~min}$, the DNA pellet was washed with $70 \%(\mathrm{v} / \mathrm{v})$ ethanol, air-dried and resuspended in TE (10 $\mathrm{mM}$ Tris-HCl, $\mathrm{pH} 8.0$, and $0.1 \mathrm{mM}$ EDTA) buffer. DNA quantifications were performed by visualizing under UV light, after electrophoresis on $0.8 \%$ (w/v) agarose gel at $50 \mathrm{~V}$ for $45 \mathrm{~min}$ and compared to a known amount of uncut lambda DNA (MBI, Fermentas, Richlands B.C., Old). The resuspended DNA was then diluted in TE buffer to $2 \mu \mathrm{g} / \mu \mathrm{L}$ concentration for use in polymerase chain reaction (PCR). Each experiment was conducted three times with four replications.

ISSR analysis - Polymerase chain reactions (PCR) with single ISSR primer was carried out in a final volume of 25 $\mu \mathrm{L}$ containing $20 \mathrm{ng}$ template DNA, $100 \mu \mathrm{M}$ of each deoxyribonucleotide triphosphate, $20 \mathrm{ng}$ of decanucleotide primer (M/S Operon Technology), $1.5 \mathrm{mM} \mathrm{MgCl}_{2}, 1 \mathrm{x}$ Taq buffer [10 $\mathrm{mM}$ Tris- $\mathrm{HCl}$ (pH 9.0), $50 \mathrm{mM} \mathrm{KCl}$, $0.001 \%$ gelatin], and $0.5 \mathrm{U}$ Taq DNA polymerase (M/S Bangalore Genei, India). Amplification was performed in a PTC-100 thermal cycler (M J Research Inc., Watertown, MA, USA) programmed for a preliminary $2 \mathrm{~min}$ denaturation step at $94^{\circ} \mathrm{C}$, followed by 40 cycles of denaturation at $94^{\circ} \mathrm{C}$ for $20 \mathrm{~s}$., annealing at required temperature for $30 \mathrm{~s}$ (Table 2) and extension at $72^{\circ} \mathrm{C}$ for $1 \mathrm{~min}$, finally at $72^{\circ} \mathrm{C}$ for $10 \mathrm{~min}$ for amplification. Amplification products were separated alongside a molecular weight marker (1.0 kb plus ladder, M/S Bangalore Genei) by $1.5 \%$ (w/v) agarose gel for ISSR analysis (Zietkiewicz et al., 1994). Electrophoresis was done in $1 \mathrm{x}$ TAE (Tris acetate EDTA) buffer, stained with ethidium bromide and visualized under UV light. Gel photographs were scanned through a Gel Doc System (Gel Doc. 2000, BioRad, California, USA) and the amplification product sizes were evaluated using the software Quantity one (BioRad, USA).

Data analysis - Data were recorded as presence (1) or absence (0) of band products from the photographic examination. Each amplification fragment was named by the source of the primer, the primer number and its approximate size in base pairs. Bands with similar mobility to those detected in the negative control, if any, were not scored. A pair-wise matrix of distance between genotypes was determined for the ISSR data using Dice formula (Nei $\& \mathrm{Li}, 1979)$ in the program Free Tree (Pavlicek et al., 1999). The average of similarity matrices was used to generate a tree by UPGMA (Unweighted PairGroup Method Arithmetic average) using the program Tree View (www. Sardinesoftware.com).

\section{RESULTS AND DISCUSSION}

Some of the molecular markers are very similar; there is still a wide range of molecular techniques (ISSR, SSR, AFLP) for researchers to select upon. One of the main challenges is, therefore, to associate the purposes of a specific project with the various molecular marker types. PCR based molecular markers have great advantages that a short well defined part of a DNA strand can amplify from a single gene or just a part of a gene. Most of the RAPD fragments amplified in one locus, and two kinds of polymorphism. Some authors found no correlation between copy number and band intensity (Semagn et al., 2006). Lema-Ruminska et al. (2008) used RAPD markers to detect the radiomutants in Chrysanthemum (Dendranthema grandiflora). However, ISSR markers involve the amplication of DNA segments present at an amplifiable distance between two identical microsatellite repeat regions oriented in opposite direction. ISSRs exhibit the specificity of microsatellite markers, but need no sequence information for primer synthesis enjoying the advantage of random markers. The present study showed that the new variants developed through sports and identify as new variants using ISSR markers. ISSR markers usually show high polymorphism although the level of polymorphism has been shown to vary with the detection method. Oliveira et al (2010) evaluated the efficiency of the touchdown method to determine the ideal PCR conditions for distinct inter-simple sequence repeat primers 


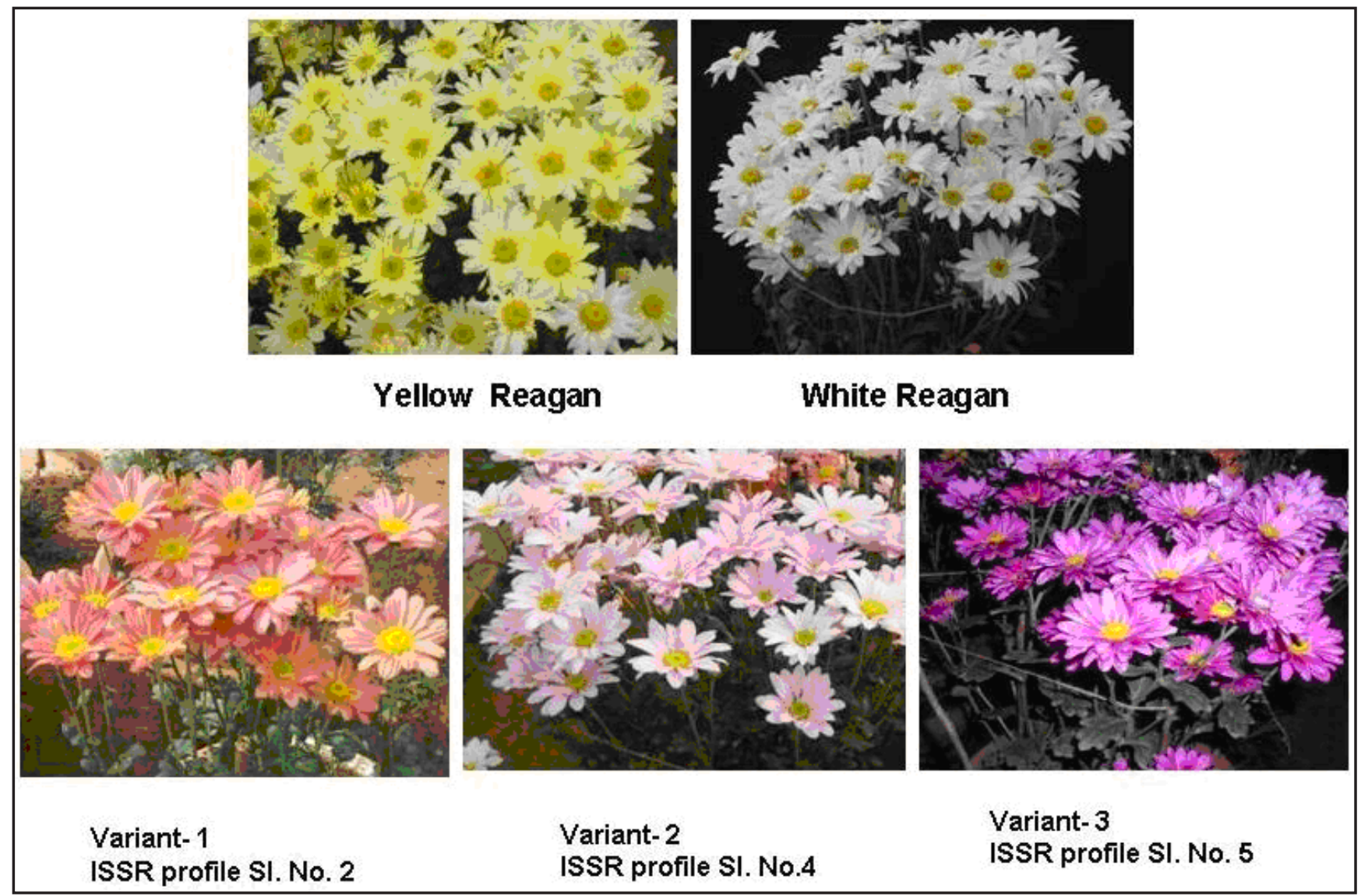

Figure 1. Variation of Chrisanthemum flower color developed through sports (variações de cor das flores de crisantemo, obtidas através de mutações). India, Regional Plant Resource, 2008.

Table 1. Morphological analysis of the cultivars (análise morfológica das cultivares). India, Regional Plant Resource, 2008.

\begin{tabular}{|c|c|c|c|c|c|}
\hline \multirow[b]{2}{*}{ Characteristics } & \multicolumn{5}{|c|}{ Name of the varieties/variants } \\
\hline & $\begin{array}{l}\text { Yellow Reagan } \\
(\text { mean } \pm \mathrm{SE})^{*}\end{array}$ & $\begin{array}{l}\text { White Reagan } \\
(\text { mean } \pm \text { SE)* }\end{array}$ & $\begin{array}{c}\text { Variant-1 } \\
(\text { mean } \pm \text { SE)* }\end{array}$ & $\begin{array}{c}\text { Variant-2 } \\
(\text { mean } \pm \mathrm{SE})^{*}\end{array}$ & $\begin{array}{c}\text { Variant-3 } \\
(\text { mean } \pm \text { SE }) *\end{array}$ \\
\hline Days until $1^{\text {st }}$ flower bud appearance & $76.0 \pm 1.3$ & $73.0 \pm 1.1$ & $79.5 \pm 1.2$ & $82.0 \pm 2.3$ & $81.5 \pm 2.1$ \\
\hline Average height of $1^{\text {st }}$ flower bud $(\mathrm{cm})$ & $49.7 \pm 1.4$ & $49.8 \pm 1.3$ & $36.5 \pm 1.1$ & $44.0 \pm 1.4$ & $33.8 \pm 1.5$ \\
\hline $\mathrm{N}^{\circ}$ of flowers/spray & $5.33 \pm 0.8$ & $5.33 \pm 0.9$ & $5.67 \pm 0.7$ & $4.67 \pm 0.6$ & $4.00 \pm 0.8$ \\
\hline $\mathrm{N}^{\circ}$ of sprays/plant & $9.33 \pm 0.9$ & $10.33 \pm 1.2$ & $8.33 \pm 0.8$ & $7.67 \pm 0.6$ & $3.67 \pm 0.7$ \\
\hline Length of spray $(\mathrm{cm})$ & $26.63 \pm 1.1$ & $31.13 \pm 1.2$ & $26.33 \pm 1.3$ & $27.3 \pm 1.6$ & $19.13 \pm 1.4$ \\
\hline Flower diameter $(\mathrm{cm})$ & $6.67 \pm 0.8$ & $6.80 \pm 0.7$ & $6.67 \pm 0.5$ & $6.50 \pm 0.7$ & $7.73 \pm 0.8$ \\
\hline $\mathrm{N}^{\circ}$ of flowers/plant & $49.8 \pm 1.0$ & $55.1 \pm 2.1$ & $47.2 \pm 1.4$ & $35.8 \pm 1.2$ & $14.7 \pm 0.8$ \\
\hline Flower weight (g) & $2.34 \pm 1.0$ & $2.13 \pm 0.8$ & $2.05 \pm 0.7$ & $2.07 \pm 0.8$ & $2.74 \pm 0.6$ \\
\hline Flower yield/plant (g) & $116.6 \pm 2.3$ & $117.6 \pm 3.5$ & $96.8 \pm 6.7$ & $74.2 \pm 5.2$ & $40.2 \pm 2.2$ \\
\hline Duration of flowering (days) & $28.0 \pm 2.7$ & $24.5 \pm 2.4$ & $25.0 \pm 2.1$ & $26.5 \pm 2.4$ & $30.0 \pm 3.1$ \\
\hline $\begin{array}{l}\text { Color (according to Royal Horticultural } \\
\text { Society color chart) }\end{array}$ & Yellow 5B & White $155 \mathrm{~A}$ & RP62D & R57A & P78A \\
\hline
\end{tabular}

*Data recorded from 15 potted plants per variety (dados obtidos de 15 plantas em vasos, por cultivar).

to detect maize hybrid. The flower colors were different in the new variants obtained through sporting as compare to other existing varieties (Figure 1). Usually, new varieties are developed either through conventional breeding method or spontaneously or artificially induced sports. But, spray type has more commercial importance than standard types. In case of spray type, the main stem pinched to encourage the growth of lateral buds, which produced more flowers in a single plant. In standard type, single main stem is allowed and produces only one large flower. The $1^{\text {st }}$ flower bud appearance and the height of $1^{\text {st }}$ bud of the variants were less as compared to the original 
Table 2. Total number of amplified fragments and number of polymorphic fragments generated by PCR using selected ISSR Primers (número total de fragmentos amplificados e número de fragmentos polimórficos gerados pelo PCR empregando ISSR Primers). India, Regional Plant Resource, 2008.

\begin{tabular}{|c|c|c|c|c|c|c|}
\hline Primers & Primer sequence & $\begin{array}{l}\text { Total } n^{0} \text { of } \\
\text { bands }\end{array}$ & $\begin{array}{c}\mathrm{N}^{\circ} \text { of } \\
\text { Polymorphic } \\
\text { bands }\end{array}$ & $\begin{array}{l}N^{0} \text { of Unique } \\
\text { bands }\end{array}$ & $\begin{array}{c}\text { Band range } \\
\text { (kbp) }\end{array}$ & $\begin{array}{c}\text { Annual } \\
\text { temperature } \\
\left({ }^{0} \mathrm{C}\right)\end{array}$ \\
\hline IG-03 & 5'GAGGGTGGAGGATCT-3' & 09 & 04 & 2 & $0.4-1.8$ & 48 \\
\hline IG-09 & $3^{\prime}-(\mathrm{AG})_{8} \mathrm{C}-5^{\prime}$ & 09 & 01 & 1 & $0.4-2.1$ & 52 \\
\hline IG-10 & $3^{\prime}-(\mathrm{AG})_{8} \mathrm{~T}-5^{\prime}$ & 05 & 01 & 0 & $0.9-1.95$ & 50 \\
\hline IG-11 & $3^{\prime}-(\mathrm{AG}){ }_{8} \mathrm{C}-5^{\prime}$ & 11 & 06 & 0 & $0.4-2.4$ & 52 \\
\hline $\begin{array}{l}\text { IG-12 } \\
\text { IG-13 }\end{array}$ & $\begin{array}{l}3^{\prime}-(\mathrm{GA})_{8} \mathrm{C}-5^{\prime} \\
3^{\prime}-(\mathrm{GA})_{8} \mathrm{~A}-5^{\prime}\end{array}$ & $\begin{array}{l}09 \\
07\end{array}$ & $\begin{array}{l}03 \\
01\end{array}$ & $\begin{array}{l}1 \\
1\end{array}$ & $\begin{array}{l}0.4-2.2 \\
0.2-1.0\end{array}$ & $\begin{array}{l}52 \\
50\end{array}$ \\
\hline
\end{tabular}

mother variety (Table 1). Sports are varieties derived vegetatively from a successful cultivar that differs from the original variety particularly in flower colors or leaf shape. It also indicated that some varieties have a less stable phenotype than others and tend to sport frequently (Wolff, 1996). Bush et al. (1993) reported that the tissue layers might help differ in a flower color and leaf morphology. Moreover, in a periclinal chimera, a bud originating from a cell of one layer may lead to a shoot with a different flower color than if the bud originated from a cell of another, genetically different (Stewart \& Derman, 1970). At the molecular level, there was a significant difference among the variants developed. Bands with same mobility were considered as identical fragments receiving equal values regardless of their staining ability. When multiple bands in a region were difficult to resolve, data of that region were not included for the analysis. As a result, six ISSR primers were selected out of twenty ISSR primers screened, as they generated clear and scorable bands with considerable polymorphism. Using six selected synthesized ISSR primers (IG-03, IG-09, IG-10, IG-11, IG-12, IG-13) can be revealed a magnitude of $32 \%$ polymorphism. The average number of amplification products per primer was eight. The size of ISSR amplified fragments varied from 0.25 to 2.4 Kbp (Table 2). The banding pattern by ISSR primer IG-10, IG-11 and IG- 13 are presented in Figure 2. The genetic variation through molecular markers has been highlighted in a number of plant species including ornamental plants
(Williams et al., 1990; Rout, 2006; Rout \& Mohapatra, 2006; Barik et al., 2006).

In the present study, it was shown that there was a significant variation between the new variants and identified varieties. Some fragments were missing in the variants and some new fragments reappeared. In case of prime IG-11, a fragment $(1.0 \mathrm{kbp})$ was missing and another new band $(1.3 \mathrm{kbp})$ appeared in variant 3 . Similar variation was also shown in primers IG-10 and IG-13 (Figure 2). They may be very close in genomes and thus amplifying similar genomic regions. The variation of DNA profile deviating with identified varieties occurs probably due to the sport arose from the cell layer. The results from the present study clearly demonstrate that the production of different polymorphisms were restricted to a specific variant or varieties. In some cases, few light bands with lower intensity appeared in the variants. The differences at the DNA level as shown in the present study were in agreement with Malaure et al. (1991a, b) and Wolff \& Peters-Van Run (1993).

In conclusion, the variants that developed spontaneously sports have different flower colors with different banding pattern as compared to other identified varieties. PCR technology can be utilized to know the variants developed through sporting and chimeras. All the primers showed variations among the variants. Missing or additional ISSR fragments should be used as marker of the variants. It will be helpful for identification of variety.

\section{ACKNOWLEDGEMENT}

The authors wish to thank the Indian Council of Agricultural Research, New Delhi for providing the laboratory facility for conducting the experiment.

\section{REFERENCES}

ANONYMOUS. 2003. Omzettabel Kamerplanten. Vakbl Bloemist 21a: 136-137.

APARAJITA S; ROUT GR. 2010. Molecular analysis of Albizia species using AFLP markers for conservation strategies. Jour. of Genetics 89: 95-98.

BARIK S; SENAPATI SK; APARAJITA S; MOHAPATRA A; Rout GR. 2006. Identification and genetic variation among Hibiscus species (Malvaceae) using RAPD markers. Z. Naturforschung. 61C: 123-128.

BUSH SR; EARLE ED; LANGHANS RW. 1993. Plantlets from petal segments, petal epidermis, and shoot tips of the periclinal chimera, Chrysanthemum morifolium 'Indianapolis'. Annals Journal of Botany 63: 729-737.

CHATTI K; SADDOUD O; SALHIHANNNACHI A; MARS MESSAOUD; MARRAKCHI M; TRIFI M. 2007. Analysis of genetic diversity and relationships in a Tunisian fig (Ficus carica) germplasm collection by microsatellite polymorphisms. J. Integr. Plant Biol., 49: 386-391.

DOYLE JJ; DOYLE JL. 1990. Isolation of plant DNA from fresh tissue. Focus 12: 13-15.

DOWRICK GJ; EL-BAYOUMI A.1966. The origin of new forms of the garden Chrysanthemum. Euphytica 15: 32-38.

GUASMI F; FERCHICHI A; FARES K; TOUIL L.2006. Identification and differentiation of Ficus carica L. cultivars using inter simple sequence repeat markers. African Jour. Biotechnology 5: 1370-1374.

JAIN SM. 2002. Feeding the world with induced mutations and biotechnology. Proc. Int. Nuclear Conference 2002 - Global trends and Perspectives. Seminar 1: Agriculture and Bioscience. Bangi, Malaysia: MINT; 2002.p. 1 LEMA-RUMIÑSKA J; ZALEWSKA M; 
SADOCH Z. 2008. Radiomutants of chrysanthemum (Dendranthema grandiflora Tzvelev) of the Lady group: RAPD analysis of the genetic diversity. Plant Breeding 123: 90-93.

MALAURE RG; BARCLAY G; POWER JB; DAVEY MR. 1991a. The production of novel plants from florets of Chrysanthemum morifolium using tissue culture. 1. Shoot regeneration from ray florets and somaclonal variations exhibited by the regenerated plants. Journal of Plant Physiology 139: 8-13.

MALAURE RS: BARCLAY G; POWER JB; DAVEY MR. 1991b. The production of novel plants from florets of Chrysanthemum morifolium using tissue culture. 2. Securing natural mutations (sports). Journal of Plant Physiology. 139: 14-18.

NEI M; LI WH. 1979. Mathematical models for studying genetic variation in terms of restriction endonucleases. Proceedings National Academy Science, USA. 76: 52695273.

OLIVEIRA EC; AMARAL JUNIOR AT; GONCALVES LSA; PENA GF; FREITAS JUNIOR SP; RIBEIRO RM; PEREIRA MG. 2010. Optimizing the efficiency of the touchdown techniqe for detecting inter-simple sequence repeat markers in corn (Zea mays). Genet. Mol. Res. 9: 835-842.

PAVLICEK A; HRDA S; FLEGR J. 1999. Free Tree - Freeware program for construction of phylogenetic trees on the basis of distance data and boot strapping/jackknife analysis of the tree robustness. Application in the RAPD analysis of the genus Frenkelia. Folia Biology 45: 97-99.

PIERIK RLM. 1991a. Micropropagation of ornamental plants. Acta Hortic 289: 45-53.

PIERIK RLM .1991b. Commercial micropropagation in Western Europe and Israel. In: Debergh PC; Zimmerman RH (eds). Micropropagation. The Netherlands: Kluwer Acad. Publ. p. 155-65.

ROUT GR; MOHAPATRA A. 2006. Use of molecular markers in ornamental plants: A Critical Reappraisal. European Journal of Horticultural Sciences 71: 53-68,

ROUT GR. 2006. Identification of Tinospora cordifolia (Willd.) Miers ex Hook F \& Thomas using RAPD markers. Z. Naturforschung 61C: 118-122.

ROUT GR, APARAJITA S. 2009. Genetic relationships among 23 Ficus accessions using Inter Simple Sequence repeat markers. J. Crop
Sci. Biotechnology, 12: 91-96.

SEMAGN K; BJORNSTAD A; NDJIONDJOP MN. 2006. An overview of molecular marker methods for plants. African Journal of Biotechnology 5: 2540-2568.

STEWART RN; DORMAN H. 1970. Somatic genetic analysis of the apical layers of chemical sports in chrysanthemum by experimental production of adventitious shoots. American Journal of Botany 57: 1061-1071.

WILLIAMS JGK; KUBELIK AR; LIVAK KJ; RAFALSKI JA; TINLEY SV. 1990. DNA polymorphisms amplified by arbitrary primers are useful as genetic markers. Nuclelic Acids Research 18: 6531-6535.

WOLFF K; PETERS-VAN RUN J. 1993. Rapid detection of genetic variability in Chrysanthemum (Dendranthema grandiflora Tzvelev.) using random primers. Heredity 71: 335-341.

WOLFF K. 1996. RAPD analysis of sporting and chimerism in chrysanthemum. Euphytica 89: 159-164.

ZIETKIEWICZ E; RAFALSKI A; LABUDA D.1994. Genomic fingerprinting by simple sequence repeat (SSR)-anchored polymerase chain reaction amplification. Genomics 20: 176-183. 